\title{
Pacific Seascapes, Canoe Performance, and a Review of Lapita Voyaging with Regard to Theories of Migration
}

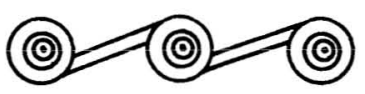

GEOFFREY IRWIN

THIS ARTICLE CONSIDERS VARIATION IN ISLAND AREA and ocean area across the Pacific, in order to compare voyaging and settlement in the Lapita domain (approximately 3000 years ago), with an earlier period in Near Oceania (late Pleistocene to mid-Holocene), and a later one in Polynesia (first and second millennium A.D.). It appears that there were different and more navigationally demanding kinds of seascape associated with these successive episodes of migration. The form and performance of canoes are discussed, including those possibly associated with Lapita colonization, and some of the practicalities of ocean voyaging and navigating in a Lapita context are examined. Finally, three models of migration are reviewed concerning (1) ENSO (El Niño-Southern Oscillation) forcing; (2) Holocene hydro-isostatic sea-level change; and (3) exploration involving strategic use of weather systems.

\section{LAND AND SEA AREAS AND THEIR RELATION TO EPISODES OF DISPERSAL IN THE PACIFIC}

Island groups differ in their areas of land and surrounding sea, and there are broad patterns of variation across the Pacific Ocean. People living on islands were obliged to negotiate the ocean, and these variations affected initial settlement and subsequent interaction. Comparison of islands involves dividing an ocean into spheres of interest to particular islands, and while the methods are necessarily arbitrary recent studies have produced coherent results which are further investigated here (Irwin 1998, 2000). Estimated values for land and sea areas are shown in Figure 1. The values for ocean area are taken from a model which establishes boundaries midway between adjacent islands to create a series of contiguous seascapes, which have each been closed with an arc of the shortest possible radius. The method (1) treats all islands alike; (2) the area of ocean in each seascape is minimized; and (3) all of the enclosed sea lies closest to the enclosed island. ${ }^{1}$ In

Geoffrey Irwin is Professor of Archaeology in the Department of Anthropology, University of Auckland. 


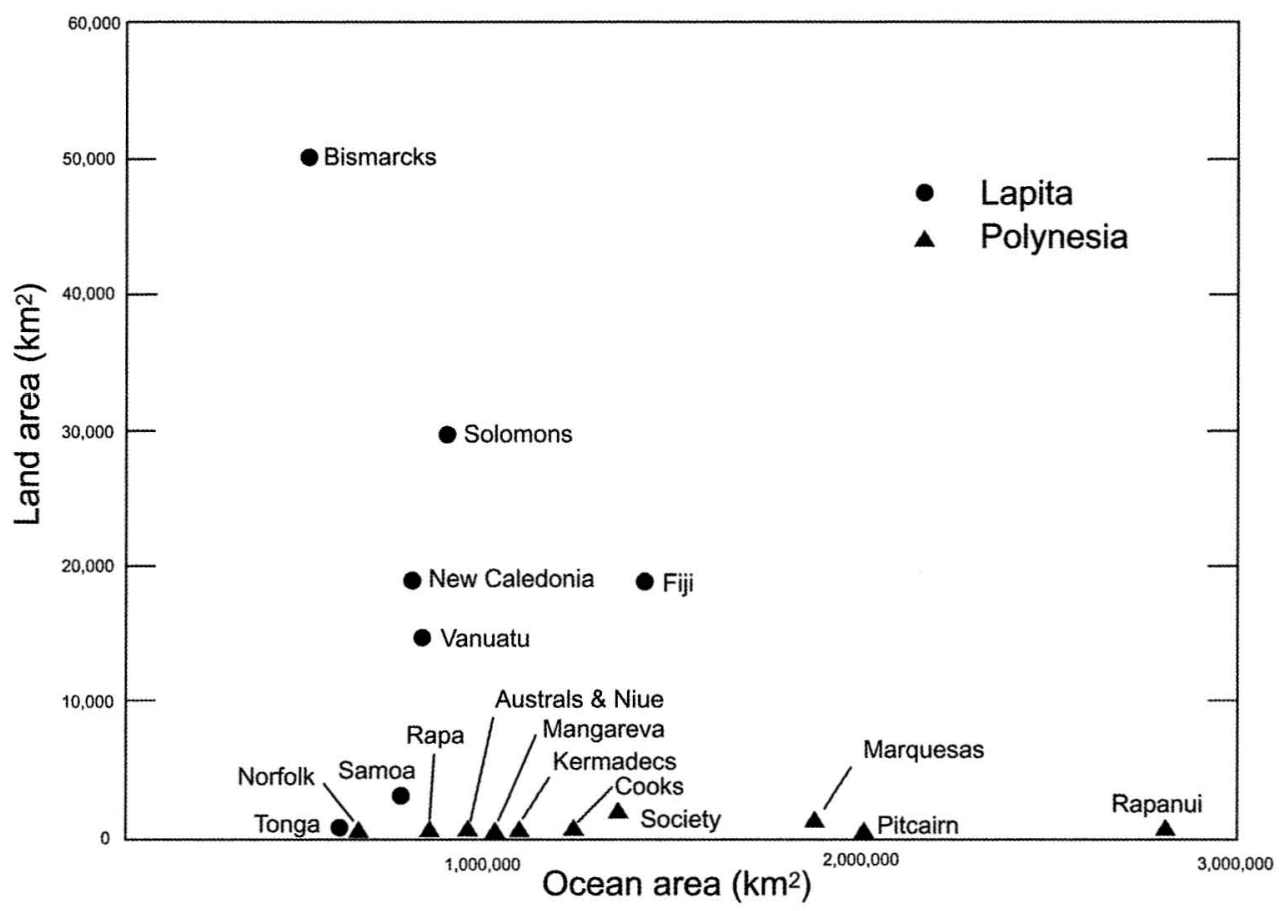

Fig. 1. Areas of land and surrounding ocean for the island groups of Melanesia and Polynesia. Hawai' $i$ and New Zealand have not been included because their values lie beyond the chart (New Zealand on the vertical scale and Hawai' $i$ on the horizontal). To include them in a chart drawn at a different scale would compress many other islands and conceal the distinctions to be seen among them. Land areas are $16,770 \mathrm{~km}^{2}$ for Hawai' $\mathrm{i}$ and $268,680 \mathrm{~km}^{2}$ for New Zealand. Calculated values for ocean areas are $8,033,586 \mathrm{~km}^{2}$ and $1,593,383 \mathrm{~km}^{2}$, respectively.

Figure 1 the islands are not plotted by latitude or longitude, but it can be seen that their relative positions in the diagram often reflect their geographical locations. The values show a separation between the Lapita and Polynesian domains and islands of West Polynesia occur between them.

In Figure 2 ratios of land area to sea area are plotted by longitude. It can be seen that a small number of islands have high ratios while the majority have low ones. The values curve steeply downwards in the west and then flatten out across the ocean. What is most striking in this diagram is that islands differ by orders of magnitude. Also, there is a clear distinction between the nature of the seascapes of the Lapita region and those of tropical East Polynesia, while the islands of West Polynesia lie between them and possibly marginal to both.

In Figure 3 the same values for land-sea area ratios are transformed logarithmically, and while this no longer shows the great differences between islands it draws many of them into a line along the diagonal that illustrates other trends. Again, we see a separation of Lapita and Polynesian seascapes. A chronological series is implied for Lapita which conforms to current $\mathrm{C}^{14}$ chronology (and would do so just on the basis of longitude). The islands of Near Oceania are followed in time by those of Remote Oceania; Tonga and Samoa straddle the divide between continental regions and the Pacific Plate. Then came the first part of the Polyne- 


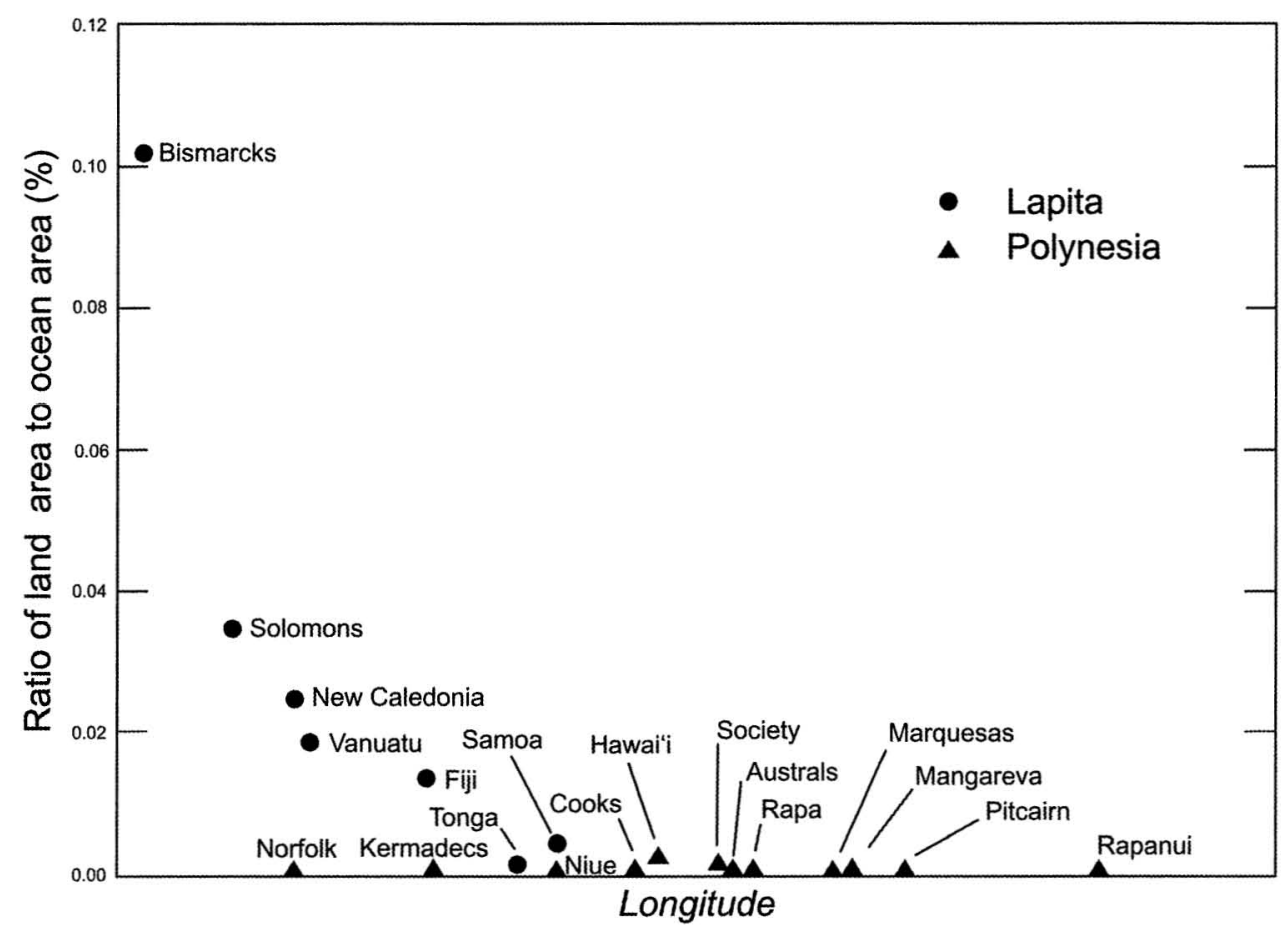

Fig. 2. Ratios of land area to ocean area plotted by longitude. There is a clear distinction between Lapita and East Polynesian seascapes, while the islands of West Polynesia lie between them. New Zealand is not plotted because it lies far above the scale of the chart; however, it is now possible to include Hawai'i.

sian pause until the settlement of Niue around 2000 B.P., followed by tropical East Polynesia. Contact with America was probably made around this time and the migrations of the Polynesians concluded in temperate and sub-Antarctic regions.

The graph draws attention to some anomalies and uncertainties. The position of the Southern Cooks and Societies could imply earlier settlement than the rest of East Polynesia (Pearsall 2000). (The Cooks have received quite a lot of attention but the Societies would certainly profit from more.) Hawai'i, too, might be thought to be earlier in terms of its land-sea area ratio, but that can be explained by its likely settlement via the Marquesas. Currently acceptable $\mathrm{C}^{14}$ dates do not distinguish the order of settlement of the remaining islands of East Polynesia, and if this episode occurred within the span of a few centuries as the dates imply, it indicates an acceleration of colonization (Kirch 2000).

The anomalous nature of southern Polynesia in the analysis is explained in terms of latitude. New Zealand was large, and near enough to be settled earlier, but Lapita migrants did not sail south; and if they had, Norfolk and the Kermadecs appear to fall below the range of Lapita settlement in terms of the area ratios. With regard to marginal limits for settlement, Tonga was the smallest group settled in the Lapita period, and at $750 \mathrm{~km}^{2}$ it was considerably larger than Niue $\left(260 \mathrm{~km}^{2}\right)$ and the Southern Cooks $\left(240 \mathrm{~km}^{2}\right)$, the next islands farther east. 


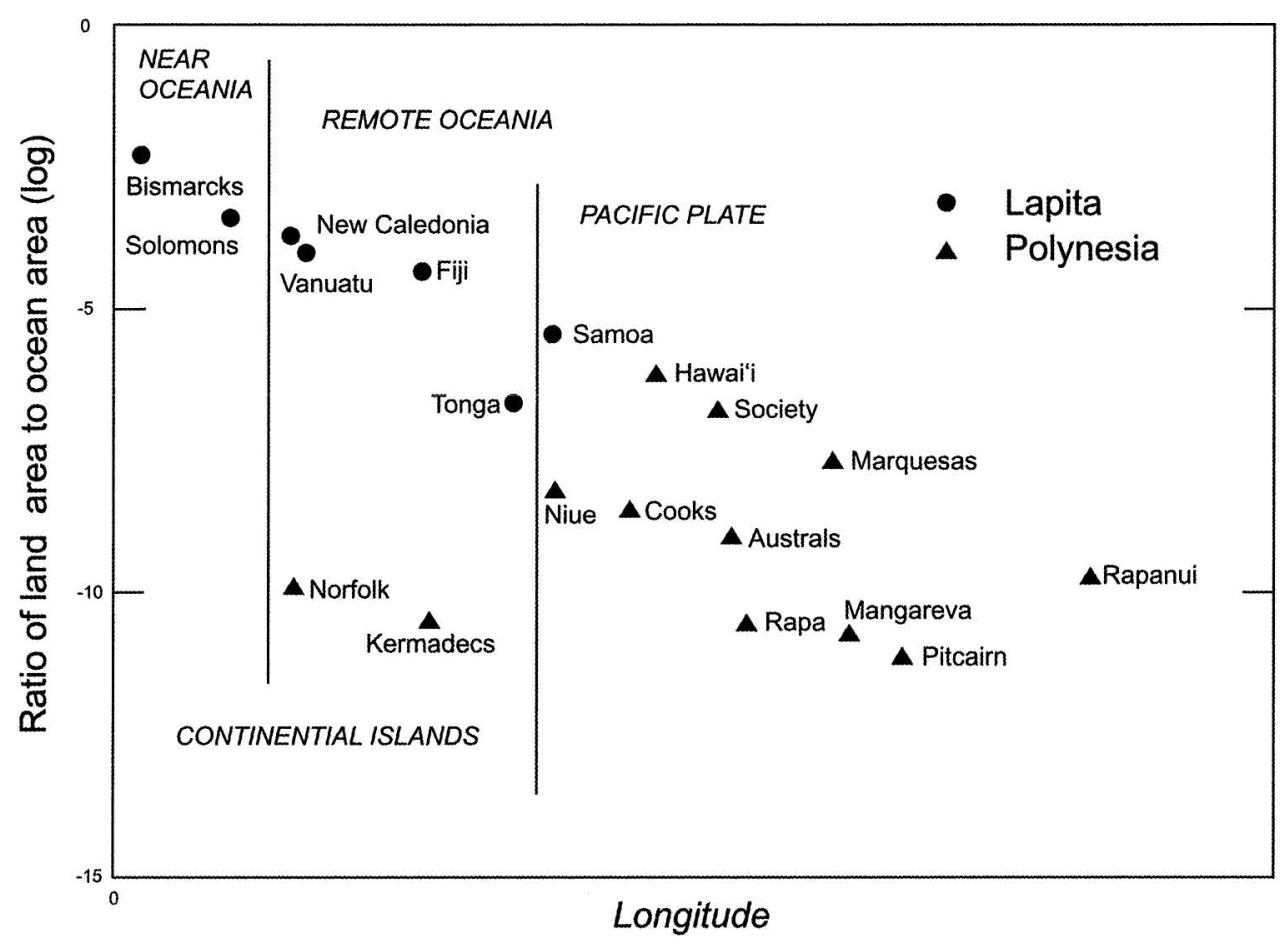

Fig. 3. Ratios of land area to ocean area, transformed logarithmically, are plotted by longitude. The diagram illustrates some general patterns of prehistory as well as some anomalies described in the text. Hawai'i is included, but New Zealand is not plotted because it lies far above the scale of the chart.

\section{CANOE DESIGN AND PERFORMANCE}

Evidence of successful ocean sailing appears abruptly in the archaeological record from the time remote islands were settled, but the prior development of the technology and associated skills must have taken place more gradually elsewhere (Irwin 2006).

\section{Lapita Canoe Form}

Lapita canoes were sufficiently large, safe, and fast to sustain an extensive maritime migration, but in the absence of any physical remains the type used is uncertain. However, reconstructed Malayo-Polynesian terms for canoe parts together with the distribution of canoe features recorded in Oceania by early European observers suggest that a likely Lapita type was a single-outrigger canoe with a hull made from dugout $\log$, and its freeboard raised with lashed-on strakes. The sail was a simple two-spar rig of a kind usually described as an "oceanic spritsail," and the canoe may have changed direction relative to the wind by some mode of tacking rather than shunting (Anderson 2000; Blust 1999; Doran 1981; Finney 2006; Haddon and Hornell 1997; Pawley and Pawley 1994). The same general 
rig type was subsequently used by double-hulled tacking canoes during the colonization of East Polynesia, but the spread of a three-spar "oceanic lateen" form was evidently much later and its distribution more restricted.

\section{The Oceanic Spritsail}

The oceanic spritsail is a fore-and-aft sail that can take the wind from either side as distinct from a kind of sail-not known in the Pacific-that takes the wind only from behind. The leading edge of a spritsail is attached to a forward spar, which is stepped on the canoe and functions rather like a mast, insofar as it transfers wind forces from the rig to the hull. The trailing edge of the sail is attached to the second spar, which functions rather like a boom as it is used to adjust the trim of the sail. This trailing spar is loosely joined at the bottom to the forward sparnot to the hull-and this characteristic is shared by the sails shown in Figure 4, which in this respect are variations of the same principle.

When under sail, modern and ethnographic Pacific spritsails are trimmed sometimes by tilting the rig, and more often by ropes (sheets) attached to the trailing spar which adjust the angle of the sail to the boat; and as the angle is changed aerodynamic forces acting on the hull turn the canoe either toward or

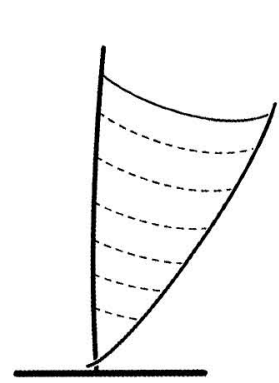

New Zealand

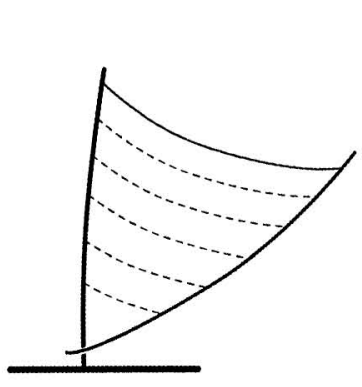

Marquesas

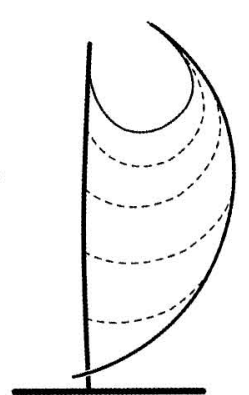

Hawai'i

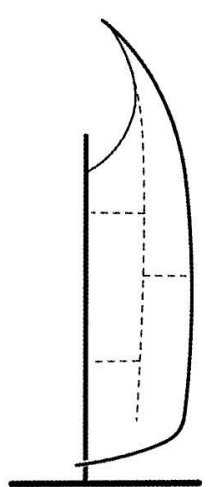

Tahiti

Fig. 4. Schematic sketches of oceanic spritsails seen by Europeans in New Zealand, the Marquesas, Hawai' $i$, and Tahiti in the 1770s (Haddon and Hornell 1997). The leading edges of the sail are to the left and trailing edges to the right. Details of standing and running rigging are not shown as the original artists' drawings may be unreliable. The meeting of the two spars in the New Zealand sketch appears in some early sketches, but is obscured in others. The sail shown in the figure is based on a written description made in 1769 (Salmond 1991:187), and on the form of an early sail held in the British Museum (Haddon and Hornell 1997: Fig. 140). Also not shown are various attached trailing fibers, which, while decorative, also served as telltales to assist the sailors in trimming the sails. These various spritsails probably shared a common ancestral form (or forms) found in Lapita canoes, but nearly 3000 years intervened before European contact and much change is likely to have occurred. Although Pacific canoes that carried spritsails are described as tacking canoes it is not unlikely that in the case of early forms, when the canoe changed tack the whole rig was taken down, the canoe maneuvered by paddle on to the new course, the sail was erected again, and trimmed to the new point of sail. Sails were probably taken down in squalls as well. 
away from the direction of the wind, which is a method of steering. Thus, spritsail canoes usually sail by reaching. On a beam reach the wind is coming from around 90 degrees; on a broad reach it comes from further aft and the canoe is traveling downwind; some canoes can tight reach when the wind is coming from ahead of the beam, but this ability depends on the construction and design.

\section{Sailing Performance}

What was the sailing performance of Lapita and other prehistoric canoes, and in what directions could they sail in relation to the direction of the wind? These are questions which bear on the choices and constraints on sailors and settlers during episodes of migration, but scholars and modern sailors differ in their views (e.g., Anderson 2000, 2003; Finney 2006). No clear answers are to be found in the performance of most modern replica canoes, but some traditional canoe types are more readily comparable.

All boats are subject to laws of physics and their application to sailing craft is well understood (Marchaj 2000). "The prediction of the performance of sailing vessels from first principles is now a well-established and reliable process, and computer models of yacht performance are extensively used by designers" (Jackson and Bailey 1996:307). For instance, when a canoe is sailing at a steady speed the aerodynamic forces of the sail are in balance with the hydrodynamic forces of the hull. The driving force of the sail produces a heeling moment (sometimes called an overturning moment) in the hull, which is resisted by a righting moment provided by the outrigger. When outriggers are lifted from the water their weight provides a lever to rotate them back to the surface; and when the rotation of the canoe hull pushes them down into the water their buoyancy restores them to the surface. As such they have been described as the world's oldest feedback mechanism (Abramovitch 2005). The roll stability of Pacific canoes, which comes from the righting moment, is fundamental to their ability to sail. In a single-outrigger canoe of the tacking kind, a form we could envisage for Lapita, the outrigger is alternately on the windward and leeward sides of the canoe; and with the outrigger to leeward its drag increases, sailing performance is impaired, and the canoe is more vulnerable to capsize. Another general characteristic is that the side forces on sail and hull are often not directly above each other, which generates a yawing moment that tends to turn the canoe one way or the other, but this is resisted by a steering paddle which keeps the canoe on course (Jackson and Bailey 1996:308).

The speed of a modern or ethnographic sailing canoe (as well as mathematical models of canoes) is affected by the driving force of its sail, and its angle to the wind, being faster on a beam reach than pointing higher into the wind or running with the wind from behind. If sailed too high the sail will stall, and too far off the wind is to risk a dangerous jibe. Another important property is leeway-the movement of the canoe sideways in the water as well as forward-which varies with the underwater cross section of the hull, and which increases as the canoe sails higher into the wind until eventually the canoe will cease to move forward at all. In addition, the direction and speed of a canoe affect the apparent direction and speed of the wind, as seen from the canoe. As the wind speed doubles its force may square, which is an issue for the strength of traditional materials. 


\section{Modeling Prehistoric Canoes}

It is fairly straightforward to model the performance of long narrow wooden hulls with various underwater profiles. Preliminary research at the University of Auckland shows that wind force data of model canoe sails can be obtained from wind tunnel testing and estimates of the speed and leeway of canoes calculated from mathematical models. Comparisons of performance have been made between different canoe types by Jacobs (2003) using wind data collected from models of lateen rigs by Jackson and Bailey (1996), but this has not yet been done for spritsails or from using fabrics made of traditional materials.

The hydrodynamic properties of early oceangoing canoes share points in common with some ethnographic ones. Lapita canoes, if based upon dug-out logs, would be similarly long and narrow. The underwater cross section of the hull could have been simpler (round) and offered less resistance to leeway, but canoe fragments from the lake village of Kohika in New Zealand indicate other late prehistoric profiles. The size and displacement of canoes used for migration would follow from the need to carry the weight of a minimal founder population. An adequate sea-keeping ability is apparent in the successful outcomes of voyaging. Canoes with sufficient roll stability have the physical capacity to sail across the wind, to some degree at least, with fore-and-aft sails. The form, size and driving force of prehistoric sails cannot be known, although estimates could be based on the hydrodynamic properties of the hull. For example, the normal heeling moment of the sail could not exceed the righting moment of the outrigger of a Lapita canoe with its outrigger to leeward, without the canoe capsizing. An adequate program of performance modeling would need to test a suitable range of models.

It is probably reasonable to think of late Pleistocene and early Holocene voyages in Wallacea and Near Oceania as lasting only a few days; of Lapita explorers operating over a period of weeks; and of their Polynesian descendants over periods of weeks and months. Long voyages to the higher latitude islands of East Polynesia and to the coast of America perhaps could have sailed the outward and return legs in different seasons or years. We know that early Europeans in the Pacific made voyages lasting months and years. There is a simple equation between canoe speed and voyage duration and, in their computer simulation of Lapita voyages, Irwin, Bickler, and Quirke (1990) estimated an average speed of 4 knots, which was based on Irwin's experience of sailing on traditional Papua New Guinea canoes, not on the performance of modern experimental canoes. It is possible that the estimate was too high for an average speed (Anderson 2000); however, the effect of using a lower speed would be only to extend the length of the voyage.

\section{The New Zealand Maori Canoe and Sail}

During the long interval between early settlement and European contact, canoe technology continued to develop in some Pacific islands, but declined in others. The New Zealand case is of the latter kind and is interesting because it has implications for early Polynesian prehistory. By Cook's time, double canoes were giving way to single ones without outrigger, especially in the North Island. Singleoutrigger canoes were already rare and at the point of disappearance and double 
hulls followed in the early decades of the nineteenth century. Haddon and Hornell $(1997: 200)$ attribute the changes to the abundance of large forest trees, and the decline in overseas voyaging. "For ordinary coastal journeys within sight of land open canoes of beam such as their Tahitian forefathers could never command required no longer the assistance of artificial stabilizing devices - the connection of two hulls or the use of a counterpoise float."

The change was followed in language. The Polynesian word *katea meaning the side of a canoe opposite the outrigger was lost with the outrigger itself. The word * kiato that refers to the booms that connect canoe hull to outrigger in island Polynesia refers instead to thwarts (seats) that stabilized the top strakes of a Maori single canoe hull (Biggs 2006:42).

Haddon and Hornell describe the Maori spritsail as having two sides attached to spars, one spar stepped in the bottom of a hull, the other secured to the first, by a rope ring or cringle, loose enough to allow it to move. Sails were permanently attached to both spars so all had to be put up or taken down together. One of Endeavour's journal keepers described the sail of the double canoe seen near Whale Island off the Bay of Plenty coast on the first of November 1769 on Cook's first expedition as

a sail of an odd construction ... made from a kind of matting, and of a triangular figure; the hypothenuse, or broadest part, being placed at the top of the mast, and ending in a point at the bottom. One of its angles was marled to the mast, and another to a spar with which they altered its position according to the direction of the wind, by changing it from side to side. (Salmond 1991:187)

Clearly one spar was at the leading edge of the sail and the other one trailed and could be trimmed as the canoe presented itself at different angles to the wind, which fits the normal spritsail model; but in Spöring's drawing of the same canoe the base of the sail is obscured by people, and may not have been a strictly accurate depiction. However, an early historic Maori sail in the British Museum, possibly from the Cook collection (Haddon and Hornell 1997:209-210), has loops to hold the spars along both the leading and trailing edges of the sail, which indicates the spars intersected at the bottom.

At the time of European contact Maori canoes were evidently sailed only downwind. Joseph Banks reported that "... we very seldom see them make use of Sails, and indeed never unless they were to go right before the wind" (Morrell 1958:139). Polack reported that “... a war (or large) canoe" could make good progress while being paddled, "... but sailing they are only enabled to proceed before the wind: beating against a head sea or adverse wind being impossible, as these canoes have little hold from their shallowness in the water" (Polack $1838: 224)$.

A fore-and-aft spritsail could allow a sailing canoe with roll stability to sail with the wind abeam, but a single canoe with no outrigger or second hull would have no righting moment to resist the heeling moment of the sail. Large single canoes could only sail downwind because, if used in any other way, they could easily capsize. This was an unusual development for Polynesia, and its significance for this discussion is not what was changed in the case of the Maori canoe, but what could have been possible for outrigger canoes since the time of Lapita-to reach across the wind, and downwind. 


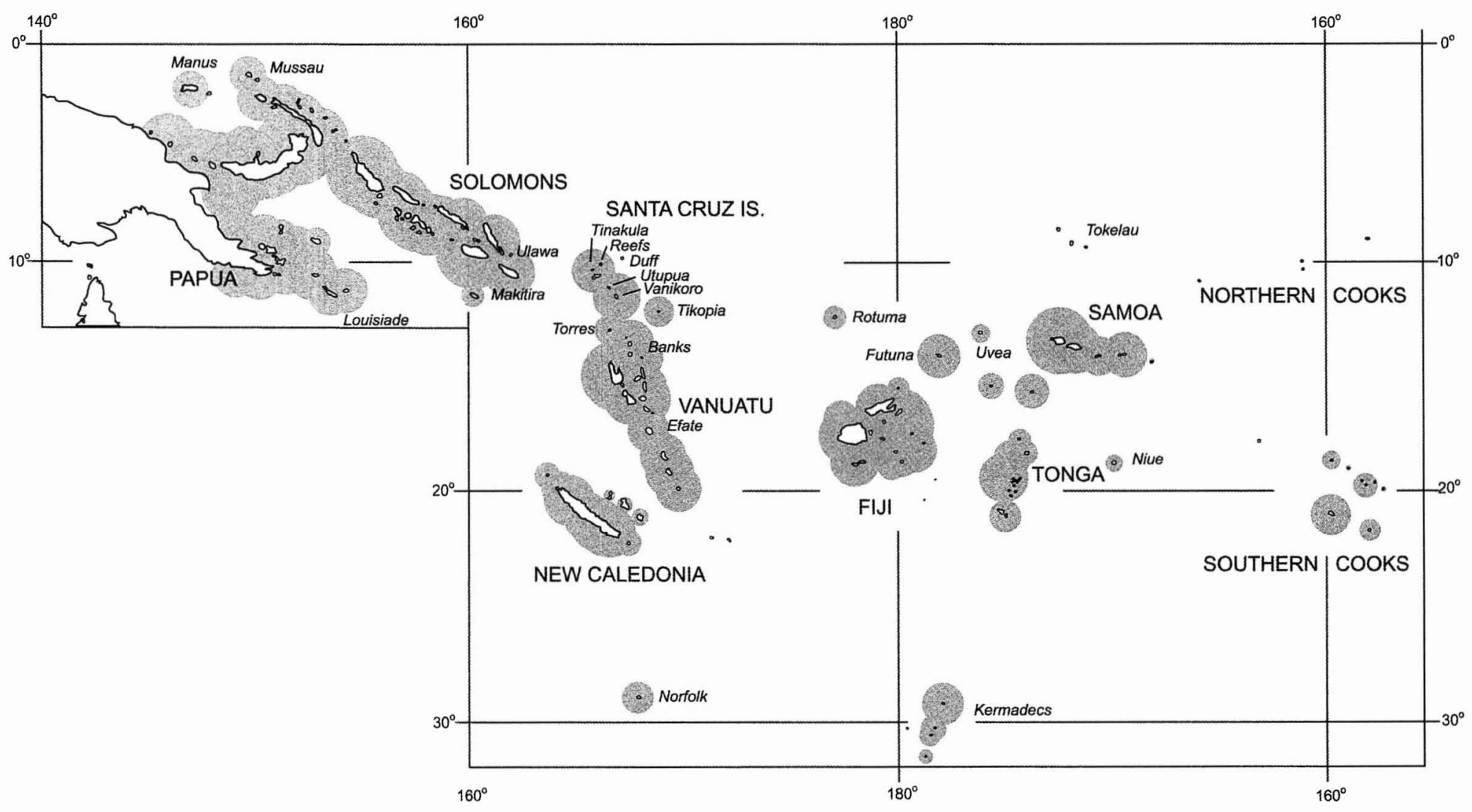

Fig. 5. Islands in the Lapita seascape. Shaded areas indicate the maximum distances from which high land can be seen from sea level, in optimal conditions. 
The earliest Lapita settlements that involved crossing open ocean were established by around $1100 \mathrm{cal}$ B.C. in the Reef/Santa Cruz Islands (Green 2003), a few centuries later than Lapita sites first appeared in the Bismarck Archipelago. These sailors had available to them the predictably alternating northwesterly monsoon winds of the Austral summer, and the southeasterly trade winds of winter. A period of high frequency of El Niño westerlies began around 3300 B.P. and lasted until c. 2500 B.P. (Anderson et al. 2006) and, if El Niño did provide a means for the Lapita dispersal (see below), then one might wonder about the delay of a century or more.

Navigation in the western part of Remote Oceania was more demanding than previously in Near Oceania, as measured by land-sea area ratios, but not as demanding as it would become farther east. While there are stretches of open ocean that required offshore voyages, several island chains could be negotiated by shorter coastal voyages. The shaded areas in Figure 5 show the maximum distances from which the highest land could be seen from sea level, and although conditions would seldom allow land to be seen from such distances, we still get a sense of the chains within which sailors could operate. For voyages out of sight of land there were large expanded targets. Commentators often emphasize the speed of Lapita dispersal, but there was actually time for some generations of sailors to experience local conditions and learn to recognize landmarks and seamarks along the way, and to pass on the accumulating information.

There are conflicting views as to whether early Lapita sites are absent from the Solomons chain or still undiscovered (Sheppard and Walter 2006), but in either case canoes could have stayed in touch with the islands as they came southward. A location at the southern end of the Solomons chain would have provided a natural departure point for the first ocean voyage of around $300 \mathrm{~km}$ out to the Santa Cruz Islands, and high land there could have assisted the landfall. This ocean leg provides the best archaeological evidence for two-way Lapita voyaging in Island Melanesia, in the form of Bismarcks obsidian and Ulawa chert which continued to arrive in Lapita settlements in the Santa Cruz group (Green 2003). Voyages south through Vanuatu to New Caledonia traversed fairly well-connected islands, but the passage across to Fiji was a long one, and additional voyages were required to carry domestic animals not in the first canoes (Davidson and Leach 2001), which indicates multiple voyages.

\section{Lapita Navigation}

We will never how Lapita sailors navigated but, given that they had oceangoing canoe technology, it is not unlikely that they had command of rudimentary levels of skill as well. For steering a course at sea they had the sun at the start and end of the day, the direction of rising and setting stars through the night, and swells during the day. They sailed among groups of large, high islands and had birds and clouds to help make landfalls. It seems likely that people would be aware of which stars passed directly overhead (in the zenith of an observer), and it is interesting that the same zenith stars passed over the south of the main Solomons chain as over the Santa Cruz Islands. To travel between them was as simple as following a zenith star path-east or west-with the seasonal winds, and this crossing was 
made again and again. Lapita sailors had the opportunity to observe the rudiments of a technique known as latitude sailing in historic times. The relatively short distances and large island targets within the Lapita seascape provided more forgiving conditions for wayfinding than in East Polynesia, where there was less latitude for error if people were to survive.

\section{What Lapita Sailors Did Not Do}

If Lapita colonists dispersed in random directions we would expect to see evidence for it, but Lapita seafarers left no archaeological evidence for crosswind or downwind voyages (with respect to the direction of the prevailing trade winds), unlike their Polynesian descendants. All successful Lapita migrants sailed in a general southeasterly direction, and could use the northwesterly monsoon of the Austral summer, and episodes of El Niño westerlies to do so. This was the direction from which canoes could most easily return under normal circumstances, implying a concern for safety (Irwin 1992).

Other options were available. Australia and Papua New Guinea were very accessible from Island Melanesia, especially with the trade winds of winter, as is obvious from the weather patterns and supported by computer simulation (Irwin 1992; Irwin, Bickler, and Quirke 1990). There was clearly land available for settlement in the Louisiade Archipelago and coastal Papua, as demonstrated by a later widespread migration of people with Lapita-derived pottery and similar patterns of settlement and economy during the first century A.D. (Irwin 1991). Norfolk and the Kermadecs could have intercepted voyages to the south had canoes sailed that way. The dispersal of Lapita appears to have been directional, and compared with what was to follow in East Micronesia and East Polynesia, even cautious and modest. But, for its time, it was remarkable on a world scale.

\section{SOME THEORIES OF SETTLEMENT IN REMOTE OCEANIA}

We can now briefly consider three current theories of Pacific settlement and look for points of agreement and disagreement.

\section{The role of ENSO (El Niño-Southern Oscillation) events (Anderson 2003; Anderson et al. 2006)}

Bridgeman (1983) suggested that climatic change from the Little Climatic Optimum to the Little Ice Age could have influenced migrations. Finney et al. (1989) showed that a canoe able to sail at 75 degrees into a headwind would need to tack four miles in distance to make good one mile to windward, and therefore it would make good sense to wait for a west wind. They invoked El Niño.

During ENSO events the average strength of trade winds decreases and westerlies blow for extended periods in ranges of latitude and longitude, which can vary with the strength of the event. Anderson and colleagues (2006) point out the correspondence of the recently established chronology of ENSO events with eastward migrations attested archaeologically.

The suggestion that episodes of El Niño assisted eastward dispersal is very reasonable. However, in addition, Anderson and colleagues also tie the episodic 
chronology of migration to the performance of canoes in prehistory, which they consider was largely restricted to downwind sailing. Thus, they see the normal technical constraints on seafaring as being lifted periodically by ENSO events.

\section{The influence of changing sea levels on the chronology of settlement (Dickinson 2003)}

Sea levels reached a meter or more above present ones around 5000 to 3000 years ago, and afterward fell to present levels. A study of the mid-Holocene hydroisostatic highstand provides a clear environmental influence for the chronology of island settlement (Dickinson 2003). During the highstand low-lying reefs were prone to flooding and atoll groups were uninhabitable. High islands, of course, could have been settled but their coastal flats were still submerged and the attractive conditions and resource base for settlement could not occur.

As an example, Fiji sea levels began to decline by 1200 B.C., Lapita arrived within 300 years, but fringing reefs were still flooded at high tide (Dickinson 2003). On Tongatapu, Lapita settlements are found on an elevated paleoshoreline, now a short distance inland which was dry at the time of occupation. Further east, in the Society Islands the decline was under way by A.D. 0, the group was more habitable by A.D. 400, and Dickinson notes archaeological indications of settlement by around A.D. 600. The atolls of Micronesia were habitable soon after A.D. 0 but those of the Tuamotus much further east did not form until A.D. 800-1200 (Dickinson 2003).

The general pattern is that migration occurred around the end of the highstand. There was more choice in the case of the high islands than for the atolls and Dickinson does not discount the possibility that some of the nearer Polynesian island groups had been discovered already. He notes that the suggestion of early deforestation and soil erosion on Mangaia in the southern Cook Islands (Kirch and Ellison 1994; Pearsall 2000) could indicate the limited presence of people during the highstand.

\section{Strategic use of weather patterns for survival (Irwin 1992, 2006)}

This theory holds that Lapita sailors made downwind and crosswind voyages of exploration and migration through Island Melanesia to West Polynesia using the northwesterly monsoon which interrupts the southeasterly trade winds in the Austral summer. In addition, there were westerly winds of subtropical origin extending right across the southern reaches of the tropics in winter, when it was possible for canoes to sail farther east, provided they had the capacity to reach across the wind. The proposition is simply that it is safer to explore first in the direction that is normally upwind to ensure the most secure return. To sail safely across the prevailing winds requires knowledge of islands to leeward of the starting island, in case it cannot be reached on the return journey. Sailing downwind may require returning by a different route through different weather systems. Two millennia of Pacific exploration provided an opportunity for navigational skills to improve with experience, and for geographical knowledge to accumulate, which would have increased the range of practical options for seafarers.

If navigators had a preference to survive as well as to settle new islands, then we could expect an archaeological outcome. In the Lapita seascape migration was 
directed against the normal direction of the trade winds. In East Polynesia the chronological order of settlement was not the order of island accessibility. New Zealand lies closer to the Lapita distribution than most of East Polynesia and offered vast resources, but it was not settled until after the tropical islands. Similarly, the large Hawai'ian group appears to have been settled through intermediary islands in an order that would follow considerations of safe dispersal. The islands of southern Polynesia lay in more dangerous directions and were later than all of the tropical islands. According to the theory that Polynesian colonization followed a general order of safety, we can rank the Kermadecs, Norfolk, and Lord Howe Island, as more dangerous from east to west, because the farther west one sailed the more difficult it would be to return east against the trade winds. At present the Kermadecs appear to have more genetic diversity of Rattus exulans than Norfolk (Matisoo-Smith and Robins 2004), suggesting more frequent contact, and no pre-European evidence has yet been found on Lord Howe.

This navigational theory of settlement gives ocean-wide coherence to the archaeological evidence, but there is no direct evidence that navigational skills required to negotiate the ocean as proposed existed in prehistory. However, conversely, the accumulating evidence for interactions between Polynesia and America could imply that they did and, most recently, Storey and colleagues (2007) have reported DNA evidence for a pre-Columbian introduction of Polynesian chickens to Chile.

\section{DISCUSSION AND CONCLUSIONS}

All three theories involve episodic colonization, which arise from the periodicity of ENSO (Anderson et al. 2006), the geological chronology of sea-level change (Dickinson 2003), or biogeographical issues discussed above (Irwin 1998, 2000). The theory of strategic (safe) sailing requires only a relative order of island settlement, whereas both ENSO and sea-level rise have more absolute $\mathrm{C}^{14}$ chronologies which may need to be reconciled.

In some respects the theories are mutually supporting; for instance, they all agree that colonization was intentional. However, there are fundamentally different opinions about the sailing performance of canoes of the migration period, and none has the support of archaeological evidence. The downwind sailing theory makes a minimum estimation of performance, which has the virtue of not overestimating it. El Niño is employed as a forcing agent and provides a loose chronology for colonization. However, it constrains the direction of advance and rather begs the question of why downwind Lapita voyages were not made westward to Papua New Guinea and Australia in La Niña conditions.

The safe sailing model rests on the distribution of basic canoe elements recorded at the time of Western contact, which indicates that canoes with roll stability and the oceanic spritsail reached virtually every island settled in the remote Pacific. It makes the inference that there was a basic ancestral form (or forms) of sailing canoe with some crosswind as well as downwind sailing capability. As compared with the minimum performance estimation of the downwind model, this is a medium rather than a maximum estimation, because it does not require the sophistication of sailing canoes that had developed in some parts of the Pacific by the end of prehistory. Nor does it depend on the performance of 
replica canoes built with modern materials, because, while they have provided valuable insights into the feasibility of non-instrument navigation and the strategic use of weather, they are not generally thought to be performance accurate.

Another point of difference is that the El Niño model of downwind colonization allows the continuation of a minimal level of sailing technology, although it does envisage the greater endurance of double-canoes replacing the singleoutrigger canoes of Lapita, from West Polynesia on (Anderson 2000). However, the safe sailing model requires improvements in canoe performance through time, and the computer simulation of Irwin, Bickler, and Quirke (1990) needed to increase levels of navigational skill (rationalized as strategies) to produce outcomes that matched archaeological patterns of settlement. Higher orders of navigational skill do seem to be required to explain the current archaeological evidence for the rapid settlement of the eastern and southern margins of Polynesia. The increasing evidence of contact with America now includes hard evidence for transportation in two directions (Storey et al. 2007). Finally, the sea-level change model does not specify canoe performance as an issue; and it does not envisage any delay between the times when islands became habitable and the times at which they were settled, which implies that the navigational competence needed to settle those islands already existed.

Different estimates of canoe performance affect issues in the study of colonization including technological capacities and constraints, agency, navigational competence, intention, and archaeological outcomes.

\section{NOTE}

1. For a more extensive discussion with examples of Pacific seascapes see Irwin $(1998,2000)$.

\section{REFERENCES CITED}

Abramovitch, D.

2005 The outrigger: A prehistoric feedback mechanism. IEEE Control Systems Magazine (August): $57-72$.

Anderson, A. J.

2000 Slow boats from China: Issues in the prehistory of Indo-Pacific seafaring, in East of Wallace's Line: Studies of past and present maritime cultures of the Indo-Pacific region: 13-50, ed. S. O'Connor and P. Veth. Rotterdam: Balkema.

2003 Initial dispersal in Remote Oceania: Pattern and explanation, in Pacific archaeology: Assessments and prospects: 71-84, ed. C. Sand. Noumea: Service des Musées et du Patrimoine de Nouvelle-Calédonie.

Anderson, A. J., J. Chappell, M. Gagan, And R. Grove

2006 Prehistoric migration in the Pacific Islands: An hypothesis of ENSO forcing. The Holocene $16: 1-6$.

BigGs, B.

2006 Kimihea te mea ngaro: Seek that which is lost. Auckland: Polynesian Society.

BLust, R.

1999 Subgrouping, circularity and extinction: Some issues in comparative linguistics, in Selected papers from the Eighth International Conference on Austronesian Linguistics: 31-94, ed. E. Zeitoun and P. J.-K. Li. Taipei: Academia Sinica.

Bridgeman, H. A.

1983 Could climatic change have had an influence on the Polynesian migrations? Palaeogeography, Palaeoclimatology', Palaeoecology 41:193-206. 
Davidson, J. M., AND B. F. Leach

2001 The strandlooper concept and economic naivety, in The archaeology of Lapita dispersal in Oceania: 115-124, ed. G. R. Clark, A. J. Anderson, and T. Vunidilo. Terra Australis 17. Canberra: Australian National University.

Dickinson, W.

2003 Impact of mid-Holocene hydro-isostatic highstand in regional sea level on habitability of islands. Journal of Coastal Research 19:489-502.

DORAN, E. JR

1981 Wangka: Austronesian canoe origins. College Station: Texas A\&M University Press.

FinNEY, B.

2006 Canoes, in Vaka Moana: Voyages of the ancestors: 100-153, ed. K. R. Howe. Auckland: Bateman.

Finney, B., P. Frost, R. Rhodes, And N. Thompson

1989 Wait for the west wind. Journal of the Polynesian Society 98:261-302.

Green, R. C.

2003 The Lapita horizon and tradition-signature for one set of Oceanic migrations, in Pacific archaeology: Assessments and prospects: 95-120, ed. C. Sand. Noumea: Service des Musées et du Patrimoine de Nouvelle-Calédonie.

Haddon, A. C., ANd J. Hornell

1997 Canoes of Oceania. Honolulu: Bishop Museum Press.

IRWIN, G.

1991 Themes in the prehistory of coastal Papua and the Massim, in Man and a half: Essays in honour of Ralph Bulmer: 503-510, ed. A. K. Pawley. Auckland: The Polynesian Society.

1992 The Prehistoric exploration and colonization of the Pacific. Cambridge: Cambridge University Press.

1998 The colonization of the Pacific: Chronological, navigational and social issues. Journal of the Polynesian Society 107:111-144.

2000 No man is an island: The importance of context in the study of the colonization of the Pacific islands, in Australian archaeologist: Collected papers in honour of Jim Allen: 393-411, ed. A. J. Anderson, and T. Murray. Canberra: Coombs Academic Press.

2006 Voyaging and settlement, in Vaka Moana: Voyages of the ancestors: 55-91, ed. K. R. Howe. Auckland: Bateman.

IRWin, G., S. Bickler, AND P. QUirke

1990 Voyaging by canoe and computer: Experiments in the settlement of the Pacific Ocean. Antiquity 64:34-50.

JAcoBs, B. A.

2003 Mathematical modeling of Oceanic canoe performance. M.A. thesis. University of Auckland.

JaCkson, P. S., AND K. I. BAiley

1996 Performance prediction of a flying proa, in Proceedings of the Waka Moana Symposium 1996: Voyages from the past to the future: 307-314, ed. H. Bader and D. McCurdy. Auckland: New Zealand National Maritime Museum.

KIRCH, P. V.

2000 On the road of the winds: An archaeological history of the Pacific Islands before European contact. Berkeley: University of California Press.

KirCh, P. V., AND J. Ellison

1994 Palaeoenvironmental evidence for human colonization of remote Oceanic islands. Antiquity $68: 310-321$.

Marchaj, C. A.

2000 Aero-hydrodynamics of sailing. St. Michaels, MD: Tiller Publishing.

Matisoo-Smith, E., And J. H. Robins

2004 Origins and dispersals of Pacific peoples: Evidence from mtDNA phylogenies of the $\mathrm{Pa}-$ cific rat. Proceedings of the National Academy of Sciences 101:9167-9172.

Morrell, W. P.

1958 Sir Joseph Banks in New Zealand. Wellington: A. H. and A. W. Reed. 
Pawley, A., AND M. Pawley

1994 Early Austronesian terms for canoe parts and seafaring, in Austronesian terminologies: Continuity and change: 329-361, ed. A. Pawley, and M. Ross. Canberra: Australian National University.

Pearsall, D. M.

2000 Paleoethnobotany: A handbook of procedures. San Diego: Academic Press.

POLACK, J. S.

1838 New Zealand. Being a narrative of travels and adventures during a residence in the country between the years 1831 and 1837. London: R. Bentley.

SALMOND, A.

1991 Two worlds: First meetings between Maori and Europeans, 1642-1772. Auckland: Viking.

Sheppard, P. J., and R. Walter

2006 A revised model of Solomon Islands culture history. Journal of the Polynesian Society $115: 47-76$

Spriggs, M.T.J.

1997 The Island Melanesians. Oxford: Blackwell.

Storey, A. A., J. M. Ramirez, D. Quiroz, D. V. Burley, D. J. Addison, R. Walter, A. J. Anderson, T. L. Hunt, J. S. Athens, L. Huynen, and E. A. Matisoo-Smith

2007 Radiocarbon and DNA evidence for a pre-Columbian introduction of Polynesian chickens to Chile. Proceedings of the National Academy of Sciences 104(25) : 10335-10339.

\section{ABSTRACT}

The first part of this paper establishes in a general kind of way that the domain or seascape that Lapita sailors operated in was more demanding than that of Wallacea and Near Oceania, but markedly less so than that negotiated later by East Polynesians. The second part takes a look at the form and performance of canoes, the possible nature of Lapita craft, and suggests ways to improve modern estimates of prehistoric performance by mechanical and mathematical modeling. The third part considers the practicalities of sailing in the Lapita domain; it argues that the dispersal of Lapita was in a selected direction rather than a random one, and offers a glimpse of how these ambitious but relatively cautious sailors learned to navigate. The final aim of the paper is to summarize three theories of migration, which support each other in some respects, but which differ in others-especially in their views of prehistoric canoe performance. Keywords: Pacific Ocean, Lapita, seascapes, canoe performance, colonization. 